\title{
Gray mold in immature fig fruit: pathogenicity and growth temperature
}

\section{Mofo cinzento em frutos imaturos de figo: patogenicidade e temperatura para crescimento}

\author{
Eliane Aparecida Rogovski Czaja ${ }^{I^{*}}$ Rafaele Regina Moreira ${ }^{\mathrm{I}}$

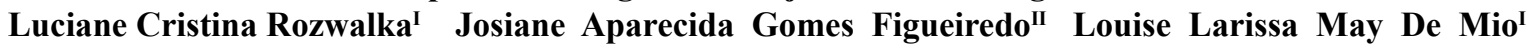

\section{- NOTE -}

\section{ABSTRACT}

Several diseases can be associated with figs but recently a fruit rot was observed in green fruit. The purpose of this study was to determine the pathogenicity of Botrytis sp., to quantify incubation period (IP) and latent period (LP), to verify the optimum temperature for mycelial growth, and to identify the different species of Botrytis sp. isolated from immature figs. Botrytis sp. isolated from figs proved to be pathogenic to immature fruit with and without wounding the fruit surface and ostiole. The IP period was 3 days on fruit with wounds and 5 days on fruit inoculated within the ostiole (without wound). The LP was 6 days in all treatments. The optimum temperature for mycelial growth was $18^{\circ} \mathrm{C}$. Inferred from sequences of a segment comprising the ITS region of ribosomal DNA concluded that the isolates are Botrytis cinerea.

Key words: Ficus carica, Botrytis sp., incubation period, latency period.

\section{RESUMO}

Várias doenças podem estar associadas com figos, mas recentemente uma podridão dos frutos foi observada em frutos verdes. $O$ objetivo deste estudo foi determinar a patogenicidade de Botrytis sp., quantificar o período de incubação (PI) e o periodo de latência $(P L)$, verificar a temperatura ótima para o crescimento micelial e identificar as diferentes espécies de Botrytis sp. isoladas a partir de frutos imaturos de figo. Botrytis sp. isolado a partir de figos provou ser patogênico em frutos imaturos com e sem ferimento na superficie dos frutos e no ostiolo. O PI foi de 3 dias em frutos com ferimento e 5 dias em frutos inoculados no ostiolo e sem ferimento. $O P L$ foi de 6 dias em todos os tratamentos. A temperatura ótima de crescimento micelial foi $18^{\circ} \mathrm{C}$. A partir de sequências de um segmento que compreende a região de ITS do DNA ribossomal, concluiu-se que os isolados são Botrytis cinerea.

Palavras-chave: Ficus carica, Botrytis sp., periodo de incubação, período de latência.
The fig tree (Ficus carica L.) is widely cultivated in the world due to its easy adaptation to different climates. The fruit is acceptable for consumption in natura (ripe), green (industry standard), and swollen or ramie. After harvesting, diseases can take place through direct access by natural openings (ostiole and peduncle) or mechanical damage (injuries) arising from handling (DURIGAN, 1999). During a survey carried out in the state of Paraná Botrytis cinerea was cited for causing symptoms in postharvest figs (VELLOZO et al., 2001). Throughout the world genus Botrytis that causes gray mold disease and was reported in several plants in both pre and post-harvest (TOFOLI et al., 2011). Occurrence of gray mold caused by Botrytis cinerea was also reported in postharvest figs (KWON et al., 2011), and in figs in pre and post-harvest in Korea (CHEONG et al., 2013). However, monocyclic components and the optimum temperature for the development of the pathogen have not been reported or investigated in Brazil, or in other parts of the world. Also, disease occurrence in immature fig fruit is still unknown.

The objectives of this study were: i) to prove the pathogenicity of Botrytis sp. to immature fig fruit; ii) to quantify the incubation period and the latent period of the pathogen on the immature fig fruit of the cultivar 'Roxo de Valinhos'; iii) to verify the minimum, maximum and optimum temperature for mycelial growth of the pathogen and; iv) to identify

\footnotetext{
'Departamento de Fitotecnia e Fitossanitarismo, Universidade Federal do Paraná (UFPR), 80035-050, Curitiba, PR, Brasil. E-mail: eliane_czaja@yahoo.com.br. "Corresponding author.

IILaboratório de Biologia Molecular, Universidade Estadual do Paraná (UNESPAR), Paranaguá, PR, Brasil. 
the specie of Botrytis sp. by means of sequences of ITS1 - 5.8 S - ITS2 Rdna. The Botrytis sp. mycelial growth and sclerotia signs were observed in immature fruits of the cultivar 'Roxo de Valinhos' harvested from domestic organic orchard, after one month of storage at $10^{\circ} \mathrm{C}$ (Figure 1A). Hyphae fragments of the pathogen associated with the immature fruit were transferred to a fresh Petri dish containing potatodextrose agar (PDA). Isolates were incubated for 5 days at $22 \pm 2{ }^{\circ} \mathrm{C}$, with light regime of 12 hours dark and 12 hours light.

After incubation, the formation of grayish colonies appeared and the characteristic structures of Botrytis sp. were observed by optical microscopy (Figure 1B). Colonies were purified by single spore isolation using water agar (WA) media. One of the purified isolate, maintained on PDA at $22 \pm 2^{\circ} \mathrm{C}$ (Figure 1C), was named BCF01-LEMID and used in this study. For the pathogenicity test, 33 immature fruits of the cultivar 'Roxo de Valinhos' (Ficus carica L.) were used. All fruits were organically produced by the Canguiri Experimental Farmin Pinhais, Paraná State.
Fruits were disinfected with $70 \%$ ethanol ( $1 \mathrm{~min}), 1 \%$ sodium hypochlorite ( $1 \mathrm{~min}$ ), and washed three times with sterile distilled water. For inoculation, mycelial plugs of $5 \mathrm{~mm}$ diameter isolated from a 7-days-old single spore culture were placed onto the ostioles opening, at the equatorial region of the immature fruit with and without wound (11 fruits per treatment). Wounds of about $2 \mathrm{~cm}$ depth were done using a sterile needle. Fruits were incubated at $22 \pm 2^{\circ} \mathrm{C}$ and lesions diameter were measured every 24 hours for 6 days, by averaging two perpendicular diameters. After the onset of signs on the lesion (Figure 1D-E), the fungus was re-isolated in PDA media to confirm the Koch's postulates. The experiment was repeated twice.

For the evaluation of mycelial growth, the $5 \mathrm{~mm}$ diameter mycelium disks were collected from the 7 days old colonies edge and transferred into the center of Petri dishes ( $7 \mathrm{~cm}$ diameter) containing PDA medium (Himedia ${ }^{\circledR}$, Sao Paulo, Brazil). The plates were incubated at temperatures of $5,10,15,20,25$, 30 and $35^{\circ} \mathrm{C}\left(1^{\text {st }}\right.$ experiment), and at temperatures of 22,24 and $27^{\circ} \mathrm{C}$ ( $2^{\text {nd }}$ experiment) under a 12 hour
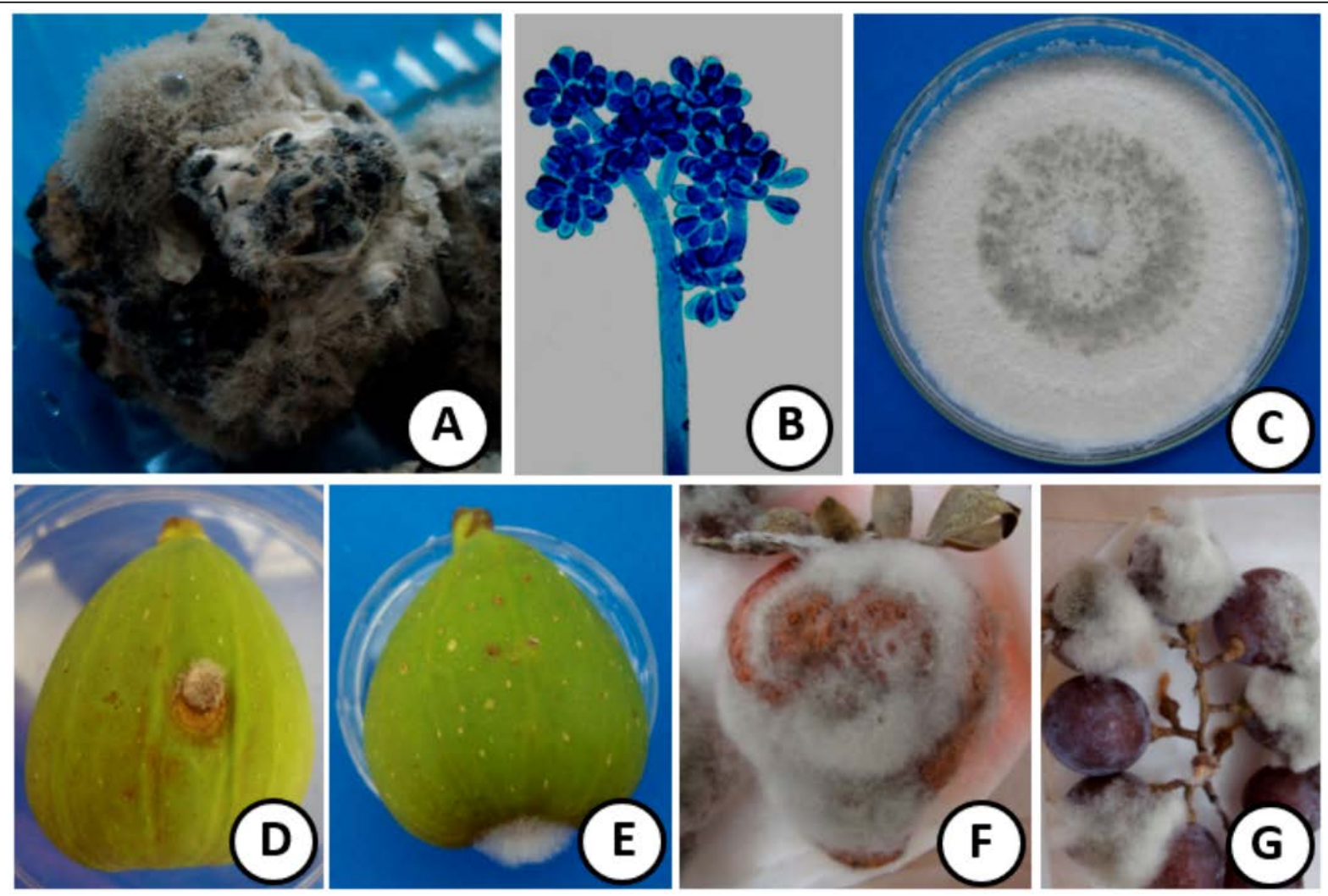

Figure 1 - Gray mold symptoms and signs of the causal agent Botrytis sp. Signs of Botrytis sp. (mycelium, conidia and sclerotia) found in immature fruit of fig stored in the refrigerator (A), light microscopy of conidia and conidiophores (B), colony of Botrytis sp. on PDA (Potato Dextrose Agar) (C), symptom induced by artificial inoculation in immature figs (Ficus carica L.) of the cultivar 'Roxo de Valinhos' on wound in the equatorial region (D) and into the opening of the ostiole (E), symptom induced by artificial inoculation in strawberry (F), and symptom induced by artificial inoculation in grape (Vitis labrusca) of the cultivar 'Niagara' $(\mathrm{G})$. 
photoperiod. Daily measurements were made until the first colony of any treatment reach the edge of the plate. The experimental design was completely randomized with three replications used for each treatment. When determining the minimum, optimum and maximum temperatures for mycelial growth, the generalized Beta function was adjusted to the data collected in the latest evaluation, according to BASSANEZI et al. (1998).

The pathogenicity of Botrytis sp. isolated from fig was also tested in fruits of strawberry and grape by inoculating fungus PDA mycelium. Fruits were maintained under $25^{\circ} \mathrm{C}$ and high humidity to confirm symptoms of the disease. For the molecular analysis fungal DNA was extracted, and the internal transcribed spacer (ITS) was amplified under the conditions described by WHITE JR. \& MORROW (1990) with primers V9G (DE HOOG et al., 1998).

The pathogenicity of Botrytis sp. in immature figs were confirmed, demonstrating the ability of the pathogen to infect immature fruit inoculated with and without wound and also, through the opening of the ostioles. However, the wounded fruits obtained the greatest severity, with the development of mean diameter lesions of $4.10 \mathrm{~cm}$ in the $1^{\text {st }}$ experiment, and $4.13 \mathrm{~cm}$ in the $2^{\text {nd }}$ experiment, differing statistically from other treatments (Table 1). This result agrees with GARRIDO \& SONEGO (2005), who reported the occurrence of symptoms caused by $\boldsymbol{B}$. cinerea in grape berries when the material had lesions caused by pest insects, cracks or other injuries.

The immature fruit inoculated with Botrytis sp. onto the opening of the ostiole and without wound were not statistically different, and showed mean diameter lesions with of $3.46 \mathrm{~cm}$ and

Table 1 - Area under the disease progress curve (AUDPC) and mean diameter of lesions, six days after the inoculation of Botrytis sp. in immature fruit of fig (Ficus carica L.) cultivar 'Roxo de Valinhos' with wound, without wound and into the opening of the ostiole. CuritibaPR, 2012.

\begin{tabular}{lcccc}
\hline Treatment & -----Experiment 1----- & ----Experiment 2----- \\
& AUDPC $^{*}$ & $\begin{array}{c}\text { Maximum } \\
\text { diameter }\end{array}$ & AUDPC & $\begin{array}{c}\text { Maximum } \\
\text { diameter }^{*}\end{array}$ \\
\hline With wound & $9.6 \mathrm{a}$ & $4.1 \mathrm{a}$ & $11.0 \mathrm{a}$ & $4.1 \mathrm{a}$ \\
Without wound & $5.7 \mathrm{~b}$ & $2.7 \mathrm{~b}$ & $7.5 \mathrm{~b}$ & $3.5 \mathrm{~b}$ \\
Ostiole & $6.1 \mathrm{~b}$ & $3.1 \mathrm{~b}$ & $7.9 \mathrm{~b}$ & $3.5 \mathrm{~b}$ \\
CV (\%) & 34.2 & 25.5 & 27.7 & 12.6 \\
\hline
\end{tabular}

${ }^{*}$ Means followed by the same letters in the columns do not differ at $5 \%$ probability by the Tukey test.

$\mathrm{CV}=$ Coefficient of Variation.
$3.52 \mathrm{~cm}$ respectively (Table 1 ). These results showed that the ostioles did not facilitate the pathogen penetration, contrary to FREIRE et al. (2006) which report that the penetration of several pathogens isolated from fig fruit with symptoms of decay was facilitated by the ostiole opening.

The incubation period of the pathogen inoculated in the wounded fruit was 3 and 2 days in the $1^{\text {st }}$ and $2^{\text {nd }}$ experiments, respectively. In fruit inoculated into the ostioles and without wound, the incubation period was 4 days. The latency period was 6 days for all treatments. There was an incidence of $100 \%$ in all treatments.

The development of Botrytis sp. isolated from fig fruit was significantly affected by temperature. The ideal temperature for d colonies development of Botrytis sp. isolated from fig fruit was $18^{\circ} \mathrm{C}$ (Figure 2). Minimum and maximum temperatures for the colonies development were 0 and $38^{\circ} \mathrm{C}$, respectively. Similar result was observed by GARRIDO \& SÔNEGO (2005), in which the development of Botrytis sp. was favored by temperatures ranging from 18 to $23^{\circ} \mathrm{C}$.

Additionally, it is very important the establishment of disease management strategies for controlling the Botrytis sp. in pre- and postharvest, mainly when temperature conditions are conducive for the disease development. It is also recommended to consider the inoculum amount in the area, and the possibility of inoculum sources from other orchards and cultures, as Botrytis sp. isolated from fig immature fruit was also able to infect and cause symptoms of gray mold in fruit of strawberry (Figure 1F) and grape (Figure 1G).

Amplification of the ITS rRNA region produced a fragment of $447 \mathrm{bp}$, that showed $98.9-100 \%$ identity to that of the representative

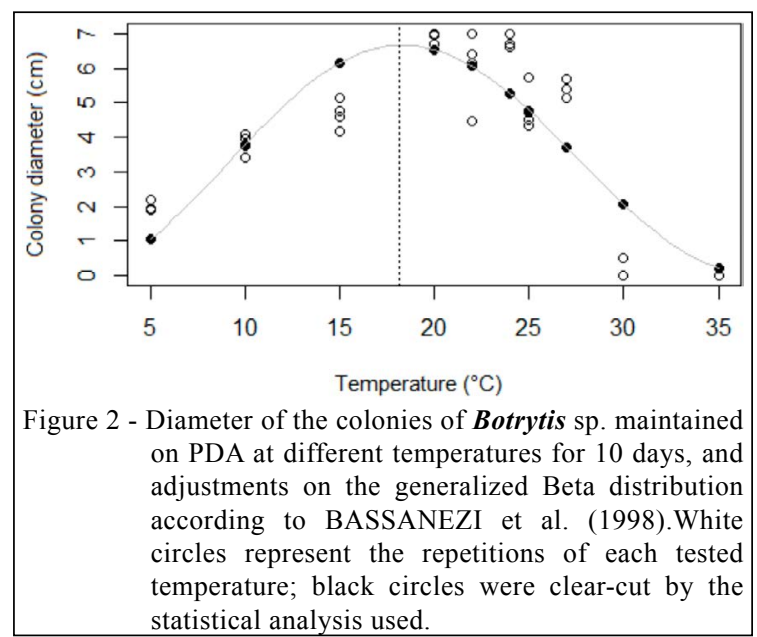

Ciência Rural, v.46, n.9, set, 2016. 
strains of $\boldsymbol{B}$. cinerea sequences deposited in the Genbank (Accession No. KT630651). This is the first report of the occurrence of this pathogen in immature fig fruit in Brazil.

\section{REFERENCES}

BASSANEZI, R.B. et al. Effects of bean line pattern mosaic virus on the monocyclic components of rust and angular leaf spot of Phaseolus bean at different temperatures. Plant Pathology, v.47, p.289-298, 1998. Available from: <http://onlinelibrary. wiley.com/doi/10.1046/j.1365-3059.1998.00239.x/ abstract>. Accessed: Dec. 21, 2014. doi: 10.1046/j.13653059.1998.00239.x.

CHEONG, S.O.et al. Occurrence of gray mold caused by Botrytis cinerea on common fig in Korea. Korean Jornal of Mycology, v.41, p.38-41, 2013. Available from: <http://www.researchgate.net/ publication/22906565>. Accessed: Dec. 21, 2014. doi: 10.4489/ MYCO.2011.39.1.052.

DURIGAN, J.F. Pós-colheita do figo. In: SIMPÓSIO BRASILEIRO SOBRE A CULTURA DA FIGUEIRA, 1999, São Paulo. Anais... Ilha Solteira: Funep, 1999. p.213-225.

FREIRE, F.C.O. et al. Doenças da figueira (Ficus carica L.) no Estado do Ceará. Fortaleza: Embrapa Agroindústris Tropical, 2006. 5p. (Boletim Técnico, 26).
GARRIDO, L.R.; SÔNEGO, O.R. Podridão cinzenta da uva: epidemiologia, sintomatologia e controle. Belo Horizonte: Embrapa uva e vinho, 1994. 21p. (Boletim Técnico, 17).

KWON, J.H. et al.First report of Botrytis cinerea as a postharvest pathogen of blueberry in Korea. Mycoliology, v.39, p.52-53, 2011. Available from: $<\mathrm{http}: / /$ www.researchgate.net/publication/264173252>. Accessed: Dec. 21, 2014. doi: 10.4489/KJM.2013.41.1.38.

TOFOLI, J.C. et al. Botrytis sp. em espécies hortícolas: hospedeiros, sintomas e manejo. São Paulo: Instituto Biológico, 2011.10p. (Boletim Técnico, 73).

VELLOZO, L.G.C.et al. Contribution to plant survey of the state of Paraná. Arquivos de Biologia e Tecnologia, v.1, p. 299-305, 2001. Available from: $<$ http://www.scielo.br/pdf/babt/vjubilee/a13vjub.pdf $\$$. Accessed: Dec. 21, 2014. doi: 10.1590/S1516-89132001000500013.

DE HOOG, G.S.; GERRITS VAN DEN ENDE, A.H.G. Molecular diagnostics of clinical strains of filamentous basidiomycetes. Mycoses, v.41, p.183-189, 1998. Available from: <http://www. ncbi.nlm.nih.gov/pubmed/9715630>. Accessed: Dec. 21, 2014. doi: 10.1111/j.1439-0507.1998.tb00321.x.

WHITE JR, J.F. et al. Endophyte-host associations in forage grasses. XII. A fungal endophyte of Trichachneinsularis belonging to Psedocercosporella. Mycology, v.82, p.218-226, 1990. Available from: <http://www.jstor.org/stable/3807534?seq=1\#page_scan tab contents>. Accessed: Dec. 21, 2014. doi: 10.2307/3807534. 